\title{
Mellem linierne
}

- Hölderlins danske figurer. En replik til Bjørnvig

\section{Jørn Erslev Andersen}

Der er ingen tvivl om, at Thorkild Bjørnvigs oversættelser af store dele af Hölderlins lyrik er en bedrift, og vi er mange, der glæder os til at gense dem i vist nok revideret form her til efteråret. Dette for at imødekomme den overraskende heftige forskrækkelse, nogle få bemærkninger i en lille tekst, jeg har forfattet, gav anledning til. Ikke blot hos Bjørnvig, som det fremgår af hans indlæg her ved siden af, men også hos nogle af dagens litterære opinionsdannere, der gik mere op i disse få bemærkninger end resten af PASSAGE nr. 10, hvori min lille tekst befandt sig. Det kunne give anledning til nogle interessante overvejelser over signaturens betydning den offentlige debat. En anden interessant diskussion kunne være den possesive signaturs egenart - hvem ejer retten til at repræsentere Hölderlin i Danmark? Men den må vi hellere lade ligge. Til benefice for den almindelige høflighed og den åbenbart nødvendige besværgelse af Bjørnvigs store betydning - jeg troede den var stærk nok i sig selv - skal jeg da knytte følgende bemærkninger til denne i sig selv ret så overflødige polemik.

At jeg kaldte Bjørnvigs oversættelser for "passionerede" var ikke ment som en karakteristik af oversættelserne, men som en karakteristik af den lidenskab, der so oder so må være investeret $\mathrm{i}$ arbejdet, og som jo da i hvert fald findes i Bjørnvigs herværende postscriptum. At jeg kaldte Bjørnvigs holdning til Hölderlin for "digteridealiserende" var deskriptivt ment og relateret til såvel oversættelserne som den indledning, Bjørnvig forsynede sin udgave fra 1970 med. Oversættelserne er ikke kun nøgterne, akademiske, de er også patetiske i deres delvist arkaiserende valg af ord. I forordet skriver Bjørnvig oplysende og klart om Hölderlins digtning. Han trækker dels på Beissners filologiske kommentarer, dels på sine egne vinkler, som Per Dahl, ganske rigtigt "glimrende", kommenterer i nævnte afsnit, hvor netop naturbegrebet giver anledning til problemer. Man kan så tilføje, at også koblingen mellem biografiske og digteriske omstændigheder (for den indforståede: Diotimas betydning) repeterer nogle givne, men i høj grad diskutable, forhold i receptionen. ${ }^{1}$ Den digteridealiserende tone spores i bemærkninger som denne:

Foruden sin mægtige begejstring havde Hölderlin et lysende intellekt, som alle store hymnikere, som Pindar, og som Ewald, og skal man danne sig et begreb om, hvad Hölderlin betyder $i$ tysk digtning, skal vi netop herhjemme tænke på Johannes Ewald (s. 12). 
Min kommentar til Højholt skal man vist være mere end almindeligt distræt læsende for at gøre til noget negativt.

Bjørnvigs ønske om at være enerådende på scenen er meget intenst, hvilket jo klart nok ligger i den sidste bitre sætning i hans postscriptum, der kun kan læses som en forurettethed, hvor den forurettede sætter sin betydning i relief ved at smække med døren (meget lidt Henry-agtigt).

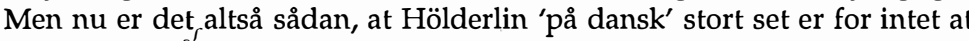
regne mod Hölderlin 'på svensk'. Og man leder i dansk sammenhæng forgæves efter store akademiske/videnskabelige studier (en sådan kan man næppe kalde Bjørnvigs forord), som er publiceret på dansk, og således har beredt grunden for en analytisk diskussion af Hölderlins digtning. ${ }^{2}$ Med al respekt for Bjørnvig, Højholt, Pia Tafdrup; Anne-Marie Mai, Per Dahl, Flemming Roland-Jensen, Jørgen Dehs, Jan Rosiek, Lis Haugaard og andre notoriske Hölderlin-læsere kan man vel derfor godt tillade sig at konkludere, at man i en akademisk/videnskabelig sammenhæng er på ganske bar grund, når man på dansk ønsker at diskutere Hölderlin. Der er ingen tradition at knytte an til. $O g$ da en sådan diskussion selvfølgelig må forholde sig til Hölderlins tyske tekster, så hjælper Bjørnvigs store indsats som formidler og oversætter ikke ret meget. Især da ikke, når man betænker, at dette at oversætte Hölderlin - akkurat som dette at oversætte f.eks. Dante, Baudelaire, Shakespeare o.a. - må bero på en række valg og vanskeligheder, som, om ikke den almindeligt interesserede læser, så i de mindste oversætteren og analytikeren må reflektere som et vilkår. Et vilkår, som bl.a. betyder, at en given oversættelse eller analyse aldrig kan betragtes som final for derefter at være immuniseret for kritik/diskussion. Det er dette, fremkomsten af Per Aage Brandts oversættelse med al ønskelig tydelighed viser. Om ikke i sig selv (hvad jeg i min lille tekst diskret forsøgte at antyde), så i det mindste i den diskussion, den her har givet anledning til (der $\mathbf{i}$ en knap så diskret form sætter problemerne i relief)

Så vidt altså Bjørnvig: man kan roligt glæde sig til genudgivelsen af hans oversættelser her til efteråret (for det er vel i bund og grund det striden står om). Og er man interesseret i såvel lyrik som Hölderlin (og Bjørnvig), så kan man såmænd også roligt anskaffe den til sit hjemmebibliotek. Det er uden for al diskussion god litteratur.

Bjørnvigs heftige reaktion kan $\mathrm{i}$ et videre perspektiv give anledning til hvad Per Aage Brandt i sit indlæg kalder en teoretisk diskussion. Nogle få konturer af en sådan kan man måske trække op sådan her.

Selv for læsere, der ikke har oversættelse behov, tyskere eller tyskkyndige altså, er Hölderlins sprog vanskeligt at tyde. Det er ikke for ingenting, han af de fleste i løbet af det 20. århundrede er blevet opfattet som en grænsedigter, der på en yderst kompleks måde sætter sproget på og i spil.
Det har nogen så valgt at kalde sprogfornyelse. Neologismer er da heller ikke et fremmedelement i Hölderlins tekster, ligesom hans anvendelse af klassiske og klassicistiske topoi undergår en mere og mere egensindigt vridende tilpasning til det digteriske univers, han udvirkede især i perioden 1800-1806. I takt hermed kan spores forskydninger i det musikalske antrit: han dyrkede med stor indforståethed og ligefremhed en række ikke latinske, men græske versformer, således i en række oder f.eks. alkæiske og asklepiadæiske former, men også, og fra 1800 især, pindarske former, ligesom hans elegier og hymner ofte anvender det metrum, der er til diskussion i Brandts og Bjørnvigs indlæg. Samtidig hermed udviklede han $\mathbf{i}$ netop sin sene digtning en række frie former, der ganske vist er yderst musikalsk/rytmisk velklingende, men som ikke organiserer sig efter faste regler ("Friedensfeier"). ${ }^{3}$ Dertil kan så føjes et yderst kontroversielt spil mellem det syntaktiske og det metriske: i de metrisk set særdeles velordnede oder, der blev udgivet i 1805 som "Nachtgesänge", er sproget brudt og kantet, med Friedrich Beissners ord kan man kalde det for brudte sætningsforbindelser, usædvanlige ordstillinger og fremmedartede billeder. Det resulterer i en kompleks udspændthed mellem metrum og syntaks, som overalt er karakteristisk for den sene Hölderlins digteriske praksis, og som Bjørnvig er ret god til at få med i sine oversættelser. Set i dette perspektiv er det en lidt vel hasarderet betragtning, Bjørnvig har i sit indlæg, at moderne digtere normalt aldrig har omvendt ordstilling. I hvert fald er inversionen et markant træk ved Hölderlins sene digtning, hvilket Hölderlin-receptionen er blevet påvist igen og igen, senest af Arne Melberg. ${ }^{4}$

Alt dette gør det vanskeligt at læse Höderlin. Og selvfølgelig endnu vanskeligere at oversætte ham. Da enhver oversættelse hviler på eller i sig selv udgør en interpretation, bliver alle disse mere eller mindre formelle problemer legeret med et semantisk problem: hvorledes skal enkeltord eller perioder oversættes i relation til den læsning, der ønskes formidlet oversættelsen? Problemet er især synligt i adjektiviseringerne (hvad betyder "hold" på hhv. hölderlinsk, tysk og dansk?), men spiller også med i forhold til f.eks. substantiverede verbalformer (som tysk, herunder Hölderlin, har mange flere af end dansk).

En oversættelse, i hvert fald af Hölderlins lyrik, har da tre felter at holde styr på, et metrisk, et syntaktisk og et semantisk. For en trænet (lyrik)-oversætter er dette en truisme, men i Hölderlins digte findes de tre niveauer spændt ud mod hinanden i en stadig vekslen, der i usædvanlig grad kræver interpretation for overhovedet at give mening. Det er denne mere eller mindre eksplicit formidlede relation, der er afgørende for, om oversættelsen kan siges enten at 'ramme tonen' eller (mindre impressionistisk) at skabe en metrisk, figurativ og syntaktisk kohærens (eller mangel på samme) i oversættelsen, der så igen kan siges at have affinitet til en tilsvarende kohærens (eller mangel på samme) i forlægget.

Endelig kan man nævne et særligt, men på ingen måde uvæsentligt, 
problem, Hölderlins tekster fremprovokerer: det filologiske. Og det på mere end én måde. For det første et klassisk filologisk perspektiv: mange af hans ord har en direkte figurativ relation til antikke tekster på måder der rækker ud over en ligefrem mimetisk, imiterende, citerende, refererende anvendelse af mytiske navne og kendte topoi. ${ }^{5}$. For det andet et regelret filologisk perspektiv: det har i løbet af det tyvende århundrede vist sig vanskeligere og vanskeligere at gestalte, så at sige, de 'rigtige' udgaver af mange af digtene fra Hölderlins senværk (1800-1806). For det tredje et editionsfilologisk: opstykningen af Hölderlins digte i tematiske blokke, der er etableret af udgiverne, viser sig at give problemer i relation til den samlede arkitektonik, de synes at etablere i deres oprindelige sammenhæng (Hölderlins foliobøger).

Alle disse her yderst sporadisk opregnede problemer gælder for så vidt oversættelser mere generelt, i hvert fald oversættelser af lyrik, men gælder med særlig accent for Hölderlins sene digtning. Tager man den fulde konsekvens heraf, lader man Hölderlin være som han er: en tysksproget digter tilgængelig (måske) for læsere, der selv bryder barrieren og lærer sig tysk. Det ville imidlertid være en konsekvens, der ville gælde for mange tekster, og ville vel også mest af alt være et udslag af misanbragt pietetsfølelse, en (alt for) højstemt forestilling om originalens eneståenhed og den slags. Selvfølgelig skal det være muligt for læsere på alle sprog at stifte bekendskab med så mange slags tekster som muligt. Men komplikationerne i realiseringen af dette kunne måske give anledning til en vis forsigtig ydmyghed: at man som såvel læser som oversætter accepterer en vis foreløbighed. At man gør sig klart, at det man fremlægger er et forslag, muligvis et blandt flere, som må acceptere de forskydninger, der sker, når andre læsere end en selv tillader sig at lægge accenterne anderledes i det sammenvævede, vekslende spil mellem metrik, syntaks og figurer, som ethvert digt lægger op til - og dermed forskyder grundlaget for en given interpretation, som da igen passende kunne udvirke en vis tøven over for fuldstændigt at acceptere denne eller hin oversættelse og, ikke mindst, dens særlige form for interpretative betingethed. Dette kan Bjørnvig vel heller ikke være uenig $i$, al den stund han jo vedholdende reviderer sine egne oversættelser. Problemet opstår tilsyneladende først, når andre blander sig med forslag til revisioner.

De to divergerende oversættelser af "Brod und Wein", Per Aage Brandt og Thorkild Bjørnvig har præsteret, lægger jo tydeligvis accenterne forskellige steder, og det på alle tre niveauer, det metriske, det syntaktiske og det semantiske (figurative). Deres diskussioner heraf foregår stort set udelukkende på et teknisk niveau. I hvert fald tilsyneladende. En nærmere analyse af deres oversættelser ville måske også vise en ikke ringe grad af interpretativ betingethed. En brandtsk Hölderlin, der giver sit musikalske sprog en lidt legende, af og til næsten helt munter, ironisk tone i kombination med alt det tungsindige, der så igen gives et let anstrøg af forurettethed. En bjørnvigsk Hölderlin, der er alvorsfuldt gude- tynget, meget højtideligt lidende og regelret patetisk. Lad så være, at der kan være tekniske (metriske, syntaktiske, semantiske) problemer i de to oversættelser, sådan som oversætterne her analyserer hinanden. Som læser af de to oversættelser får man i hvert fald leveret to vidt forskellige og på hver deres måde ganske interessante læsninger af Hölderlin. To læsninger i form af to forskellige oversættelser, som vælger at være tro mod deres forlæg på to forskellige måder, men begge sådan, at de er gennemførte og særdeles gennemtænkte. Og netop tro mod deres forlæg: hvad læserne her tilbydes er to hver for sig pålidelige og velgennemførte oversættelser, som, hvis de kunne holde ud at være i stue sammen (eller f.eks. begge var blevet optrykt i herværende periodicas 10 . nummer), ville realisere det, ingen blot tysklæsende kunne få: to udgaver af den samme tekst realisere som to forskellige former for læsninger eller interpretationer. Eller med andre ord: den umulige oversættelse ville i kraft af forskelligheden i fordoblingens anden potens forskyde sig fra en forestilling om at være lige så endegyldig og einmalig som forlægget til mindre dramatisk at blive det, enhver oversættelse vel er: et forslag til en læsning. Både Brandt og Bjørnvig lægger for så vidt op til en sådan argumentation for deres respektive valg af strategier for oversættelse, men kun i form af kategoriske og/ eller polemiske bisætninger isprængt de mere tekniske redegørelser.

Skulle man finde et sted, hvor de to læsninger diskret, men markant, antyder nogle interpretative perspektiver, kunne det være $\mathrm{i}$ de to oversættelser af det spørgsmål i digtet, som især efter Heideggers kommentar til Rilke er blevet berømt: "wozu Dichter in dürftiger Zeit". Bjørnvig oversætter adjektivet med "karrig", Brandt med "tarvelig". Bjørnvig kommenterer Brandts oversættelse på denne måde: "Dürftig kan betyde tarvelig. Men ikke her". Hvorfor ikke? Den kontante afvisning af Brandts forslag må hvile på andet end en fornemmelse, måske på en fortolkning: at det er en tid, der ikke er ødsel med muligheder, en påholdende tid, en tid, der kun giver mulighed for indfrielsen af det mest nødtørftige. Brandts "tarvelige" tid er mere direkte dobbelttydig end Bjørnvigs "karrighed": tarvelig betyder jo både nødtørftig i en ikkepejorativ betydning (at noget er lige netop tilstrækkeligt) og mangelfuld i en klart pejorativ moralsk betydning: ringe, dårlig hhv. svigt $i$ anstændighed o.lign. Bjørnvigs oversættelse er altså entydig i sin semantiske interpretation, Brandts lægger op til en flertydighed. Er det begrundet $i$ to særlige former for interpretationer eller er valgene foretaget af blot tekniske (metriske) hensyn (to hhv. tre stavelser)? Bjørnvigs udmelding er jo klar nok, han semantiserer problemet. Brandt kan derimod henvise til digtets skandering. Men i begge tilfælde lægges der op til en særlig form for interpretation af en ret omfattende kommenteret periode i digtet. begge tilfælde stabiliseres (afhistoriseres) tiden nemlig adjektivisk, mens perioden i digtet ellers ofte læses som markerende en overgangstid, hvilket på det semantiske niveau er tydeligt i den tyske version, men ikke i de danske. I sin analyse af digtet i PASSAGE nr. 10 kommenterer Lars S. 
Arndal netop disse to forskellige oversættelser i relation til en interpretativ refleksion. Han skriver således, at det at

tiden er "dürftig" (hverken Per Aage Brandts "tarvelig" eller Bjørnvigs "karrig" får betydningen af trængende - ventende på sin forløsning - med) betyder, at blik ket her mod slutningen for alvor kan vendes mod den kommende Gud - eller rettere mod den tid, hvor delingen kan betragtes som ophævet (...) (p. 79).

Man kunne måske løse problemet ved at forskyde Arndals "trængende" retning af "betrængt". Derved åbnes for udpegningen af en anden mulig aktiv instans end tiden selv, nemlig det uvisse, endnu ikke realiserede, som skal forløse tidens og dermed digterens trængsler.

Kan man af en oversættelse forvente, at den giver indtryk af at reflektere sådanne betydninger? Måske. Men man må i hvert fald forvente, at en oversættelse reflekterer sin egen interpretation i valget af ord at oversætte med, når stedet er så fortættet som det er, en fortætning, som enhver, der blot sporadisk har bekymret sig om Hölderlin-receptionen, ikke kan undgå at bemærke. Eller med andre ord: da vi går ud fra, at oversætterne netop her har gjort sig umage for at markere deres egne læsninger i relation til et tæt kommenteret, fortættet betydningskompleks af interpretativ art, der rækker ud over det rent tekniske og ind i hele digtets konstruktion, så må de valgte ord - karrig hhv. tarvelig - også bero på en mere omfattende interpretation af digtets udpegning af sin egen funktion i en tid, hvori der, som der jo står i digtet, må ventes. Måske ville en sådan undersøgelse vise, at der på en overraskende måde er både forskel og lighed mellem de to læsninger. Lighed: at tiden i begge læsninger ikke reflekteres som en overgang, men som et givet vilkår. Forskel: at denne tids muligheder er bestemt af en snerrende påholdenhed ("karrig") hhv. en mere åben flertydighed, der giver anledning til en vis konfrontativ forurettethed ("tarvelig"). Men problemet er måske snarere af teknisk art, bestemt af forskelle i valg af tekniske accenter de to oversættere imellem og uformidlelige forskelle mellem tysk og dansk?

En oversættelse har til opgave at være både tro og utro. Det har med dens særlige opgave at gøre: $i$ et helt andet sprog at gentage en sproglig begivenhed i ét sprog. Den skal føre en figur gennem en transformation, der både mimer og forskyder. Mime: den skal være så tæt på forlægge som muligt. Forskydning: den skal gøre det i et andet sprog. En oversættelse er en slags transfiguration. Det betyder som bekendt Krist forklarelse på Bjerget. Hvad oversættelsen skal 'forklare' er imidlertid knap så storslået, som det, der sker i denne urtekstlige begivenhed. En oversættelse skal, helt enkelt og ligefremt profant, 'forklare' en sproglig begivenhed på et andet, for givne læsere utilgængeligt sprog. Hvad den imidlertid mest af alt kommer til at forklare, er i dette forsøg på regelret forklaring en fremvisning af mulige læsninger af det digt, der i den transfigurative proces $-\mathrm{i}$ den vanskelige balanceakt mellem gendigtning og interlinearversion - kan læses med nye briller i kraft af netop dette. Men en Hölderlin kan aldrig være en Hölderlin på dansk. Højst en brandtsk eller en bjørnvigsk Hölderlin. Striden kan da stå om dette og, hvad der er mere perspektivrigt end striden om retten til at repræsentere Hölderlin på dansk, de interpretative detaljer, de to oversættelser hver for sig er så righoldige på. Ikke mindst jo i sammenligningen med deres alt andet end klart rindende kilde: Hölderlins digte på tysk.

\section{Noter}

1. at Hölderlins dobbelte tab af Susette Gontard, forst i form af adskillelse i 1798 dernæst $\mathrm{i}$ form af hendes død i 1802, skulle være den afgørende begrundelse for dele af hans digtning efter $i$ hvert fald 1802. Det har ført til en læsning af hans "Nachtgesänge", som først i 1989 i Hölderlin, Bevestigter Gesang v. D. Uffhausen (Stuttgart) genudgives i samlet form, der i overensstemmelse med traditionen anskuer dem som et requiem for den tabte elskede. Bjørnvig har også denne figur, om end han relativerer den en smule. Min opfattelse, som bl.a. blev fremlagt i en forelæsning for nylig, er, at sangene snarere er et requiem for en tabt, digterisk uskyld, altså en poetik. At gentage figuren 'Diotimas betydning' på det biografisk-digteriske plan er at gentage en traderet læsning, der ikke gør sig den ulejlighed at læse "Nachtgesänge" $i$ sin helhed. Konsekvent nok følger Bjørnvig da også $i$ sin oversettelse Beissners markelige og ubegrundede editionsilogiske princip om aversættelse Beissners mærkelige og ubegrundede editionsfilogiske

2. pricip on por er Fing Roland-Jenens Holderlns Muse, der bestar af en rekonstruktion og analyse af "Die ing ingen vej for et dansklasende publikum.

"Wechsel der Töne".

4. Arne Melberg "Heideggers Hölderlin", Res Publica 20, Stockholm 1992.

5. cf. Albrecht Seifert, Untersuchungen zu Hölderlins Pindar-Rezeption, München 1982. I min afhandling Som $i$ Orcus. Den. tragiske casur $i$ Friedrich Hölderlins digtning genfindes sådanne retorisk-transformative spil i relation til Euripides, Bacchae. 